\title{
GREEN INFRASTRUCTURE AS A FACILITATOR OF SUSTAINABLE SPATIAL DEVELOPMENT IN RURAL AREAS: EXPERIENCES FROM THE VIPAVA VALLEY (SLOVENIA)
}

\author{
Simon Kušar ${ }^{1}$
}

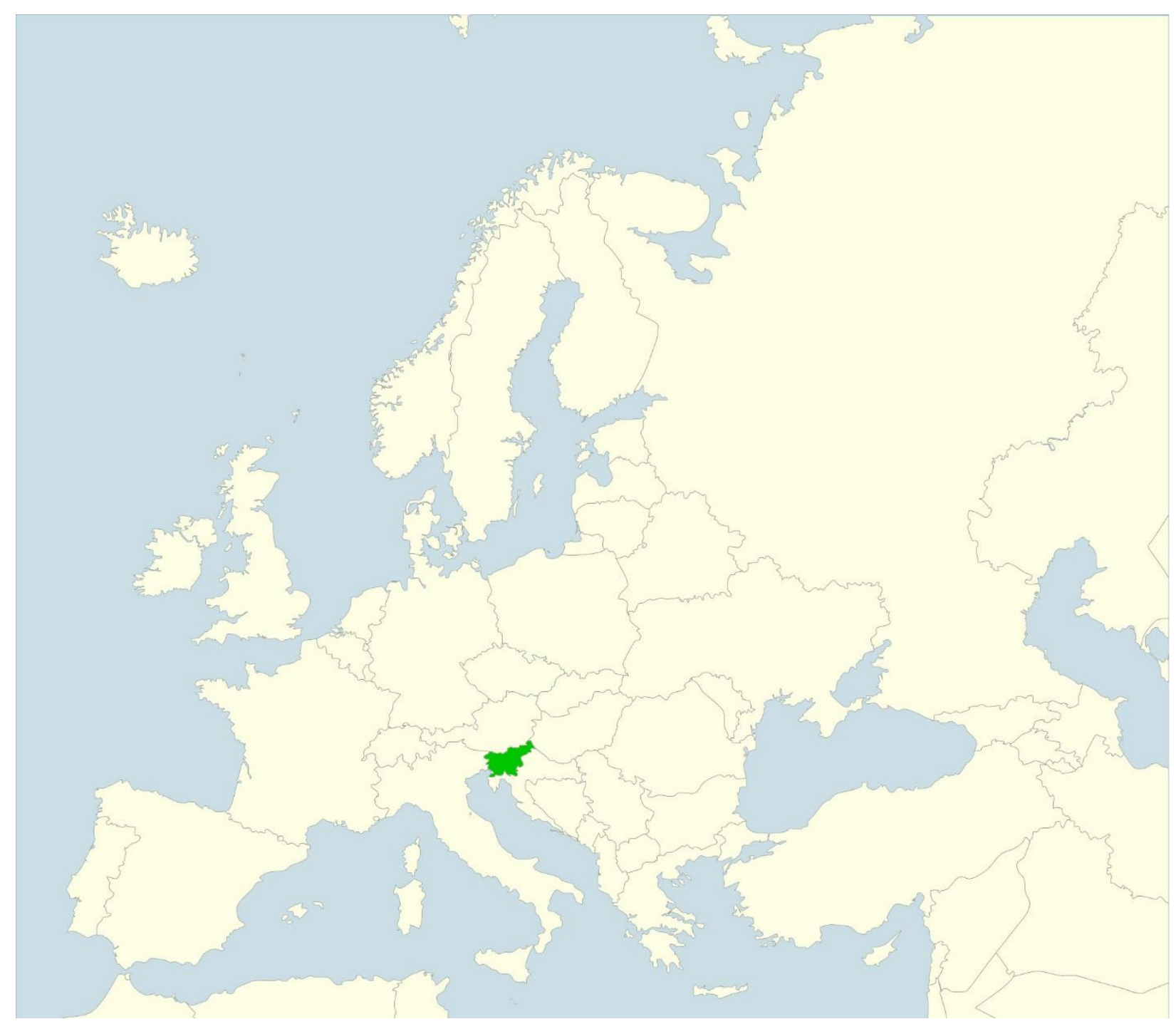

${ }^{1}$ Simon Kušar, PhD., Associate Prof., University of Ljubljana, Faculty of Arts, Department of Geography, Aškerčeva 2, SI-1000 Ljubljana, Slovenia; e-mail: simon.kusar@ff.uni-lj.si; ORCID: 0000-0002-0074-3539 
Abstract: Although the green infrastructure concept should be implemented in both urban and rural areas, only few studies investigate the green infrastructure concept in the rural settings. This paper contributes to the relevant discussion by analysing how green infrastructure can serve as a facilitator to sustainable spatial development in the predominantly rural area and at the regional level based on the planning experiences from the Vipava Valley (Vipavska dolina), Slovenia. The Vipava Approach is a bottom-up approach that understands green infrastructure in the broader developmental context and not only as a protection or land-use planning. Planning green infrastructure in rural areas should have characteristics of participatory planning on the local level, but it needs to take into account other territorial dimensions of planning as well. It needs to be holistic by addressing key developmental problems on the basis of a strategic development document.

Key words: regional planning, sustainable development, bottom-up approach, green infrastructure, Vipava Valley, Slovenia

Povzetek: Čeprav naj bi koncept zelene infrastrukture uresničevali tako na urbanih kot podeželskih območjih, le malo študij obravnava koncept zelene infrastrukture $\checkmark$ podeželskih okoljih. Članek želi na osnovi načrtovalskih izkušenj iz Vipavske doline v Sloveniji prikazati, kako lahko zelena infrastruktura služi kot spodbujevalec trajnostnega prostorskega razvoja na pretežno podeželskem območju in na regionalni ravni. Vipavski pristop je pristop od spodaj navzgor, ki zeleno infrastrukturo razume $v$ širšem razvojnem kontekstu in ne samo kot varovanje ali načrtovanje rabe prostora. Načrtovanje zelene infrastrukture na podeželskih območjih mora imeti značilnosti participativnega načrtovanja na lokalni ravni, vendar mora upoštevati tudi druge prostorske ravni načrtovanja. Pristop mora biti celosten, tako da obravnava vse ključne razvojne probleme na podlagi strateškega razvojnega dokumenta.

Ključne besede: regionalno planiranje, trajnostni razvoj, pristop od spodaj navzgor, zelena infrastruktura, Vipavska dolina, Slovenija

\section{Introduction}

In the last years, the green infrastructure approach has gained its role in both, academic debates highlighting a wide array of its role and in the planning practice at different levels, from the city to the supranational level (Lerner \& Allen, 2012; Mell, 2010; Allen III, 2012; Ahern, 2013; Mell, 2013; Kolcsár \& Szilassi, 2018). Although the term "green infrastructure" is relatively novel in Europe, its concept is not something completely new (Benedict \& McMahon, 2002). The green infrastructure approach reached Europe in its current form via the United Kingdom before 2010 (Kambites \& Owen, 2006; Mell, 2010). The European Commission highlighted its role in 2013 when it became a policy concept for achieving the environmental, economic and social goals of the sustainable development in the European Union. By definition, green infrastructure is a strategically planned network of natural and semi-natural areas that are designed and managed to deliver a wide range of ecosystem services (European Environmental Agency, 2011; European Commission, 2013). They include the provision of food, water, materials and resources, regulation of air quality and waters, erosion protection and enabling various amenities important for the human well-being (e.g., the opportunities for tourism and recreation, formal and informal education; de Groot et al., 2010). Green infrastructure is not limited only to green areas but it includes also other physical features like blue (water) areas. It is present in the urban and rural settings and defined at different territorial scales: local, regional, national, and macro-regional (Lafortezza et al., 2013; Naumann et al., 2011). 
Although green infrastructure concept should be implemented in both urban and rural areas with special emphasis on interconnecting urban and rural areas (European Commission, 2013), majority of studies and research projects investigate potentials of green infrastructure and planning approaches for its development in urban areas (Elbakidze et al., 2017). Only few studies have investigated the green infrastructure concept in the rural settings (e.g., Andersson et al., 2013; Oteros-Rozas et al., 2014; Villamor et al., 2014; Scholte et al., 2015; Elbakidze et al., 2017). A similar situation is also in Slovenia. There have been some efforts on scientific level (Bulc et al., 2014; Nastran \& Železnikar, 2016; Železnikar et al., 2017) and on the project level (AgriGo4Cities, GreenSurge, Urban Green Belts) but they are all from urban environments. Only Bokal et al. (2017a) and Bokal et al. (2017b) focus on green infrastructure in rural environments. Better prospects for the implementation of green infrastructure approach present the national spatial development strategy in preparation. Namely, national spatial development strategy sees green infrastructure as one of the most important topics at promoting sustainable spatial development (Penko Seidl et al., 2017).

Spatial planning has an important role in the development of the green infrastructure. According to the European Environment Agency (2011), green infrastructure should be developed by implementing a wide range of environmental policies, which lead towards an integrated and coherent land management and spatial planning. Spatial planning at the strategic level is seen as the most appropriate approach that enables planning the interconnectedness of various land use types in the wider geographical area (such as a region or municipality) and to help coordinate different sectors.

Since the green infrastructure approach continues to evolve (Mell, 2015), several issues regarding the practical dimension of its development has arisen. The approaches in the green infrastructure planning differ between the macro-territorial levels and the regional and local scale. Regional and local scale are more suitable for reflecting local characteristics and place-specific goals. Especially at the local scales, a number of actors is included in the planning process, either through invitation or through their personal engagement to participate in the project development (Mell, 2015). On the other hand, Lafortezza et al. (2013) highlight the problem of the implementation of the green infrastructure concept within the constraints of formal (top-down) territorial planning. There is also the vague connection of the land-use planning with social and ecological outcomes. In addition, Allen III (2012) discusses issues in changing the traditional grey infrastructure development with the green infrastructure approach. The latter is, compared to the traditional approach, more structured, holistic and integrated (Kambites \& Owen, 2006; Aherm, 2013). The implementation of the green infrastructure concept across different scales and jurisdictional boundaries that make sense in terms of their benefits and economies should also be considered (Allen III, 2012).

Lack of evidence on green infrastructure planning in rural areas and issues regarding the implementation of the green infrastructural concept show, that there are still major gaps in understanding the role and potentials of green infrastructure concept to achieve sustainable spatial development in rural areas. This paper contributes to the discussion on above-mentioned issues by analysing experiences from the recent planning process done on the green infrastructure development in Vipava Valley (Vipavska dolina), Slovenia. We are analysing the Vipava Approach mainly through defining its territorial dimension; who is doing planning and how the planning process is guided (institutional dimension), which methods and tools are used, what are the outcomes of the planning process, and what are the limitations and opportunities of the green infrastructure planning in a rural area as shown in the case from the Vipava Valley. We focus on the developmental dimension of green infrastructure and especially on the multi-scale dimension of green infrastructure planning in the Vipava Valley. The spatial planning process addressed in the paper is an example of how green infrastructure can serve as a facilitator to sustainable spatial development in the predominantly rural area and at the regional level. For practical reasons, the planning efforts for the sustainable spatial development in the Vipava Valley would be addressed as the "Vipava Approach", without an ambition to introduce a specific model for green infrastructure planning in rural areas and at the regional level at this stage. 
The paper has three main parts: the first part presents the territorial and developmental context in which the Vipava Approach emerged together with its basic characteristics; the second part gives a special attention to the institutional and territorial dimensions of the approach, while the last part (discussion and conclusions) highlights main challenges in the field of planning practice and suggest possible future development of the Vipava Apprach.

We use a range of qualitative methods in the paper in order to describe and evaluate the green infrastructure planning efforts in the Vipava Valley. Partly, this is the ethnographic study because the author of the paper was partly engaged in the planning process, meaning that he observed and evaluated, but also contributed to the development of the Vipava Approach as well. Other methods are analysis of written sources, especially the informal document entitled "Vision for the Vipava River" (Vizija za Vipavo) constructed by Bricelj et al. (2015) that proposes the basic directions of what we named as the Vipava Approach.

\section{Spatial and Developmental Context of the Vipava Approach}

The Vipava Valley is located in the western part of Slovenia. It is a $310 \mathrm{~km}^{2}$ large relief depression in the northwest - southeast direction, lying between the high Dinaric mountains and plateaus (Trnovski gozd, Hrušica, Nanos) in the north and east, karst plateau (Kras) in the south and Friuli plain in the west. Morphologically, it is not merely a plain but has an important share of hills (Vipavska brda, flysch area between the Branica River and the Vipava River, mountainous Vrhe). The region is marked by the sub-Mediterranean climate with relatively warm winters and hot summers, but with an average of $1500 \mathrm{~mm}$ of rain each year. The physical-geographical characteristics influenced the economic specialization of the region where agriculture still plays an important role with specialization in fruits, grapes, wheat and corn. Actually, the Vipava Valley is usually described as an intensively cultivated region with dense population (203 inhab./ $\mathrm{km}^{2}-$ twice of the national average). The settlement network is very dispersed with a number of small rural settlements, a limited number of small urban settlements and with a polycentric industrial spatial structure. The Vipava Valley has a favourable traffic position because it offers the shortest connection between northern Italy and central parts of Europe (Kladnik \& Natek, 2001).

The Vipava Valley got its name by the Vipava River. The Vipava River is a dominant geographical element in the region, which defined the economic structure of the Vipava Valley in the past, but after the melioration projects that took place in the 1980s, it lost its traditional role. Although melioration works increased the economic value of agriculture in the region and enabled the modern agricultural production, they caused various spatial and environmental problems. Particularly, they were not performed well and they were not considering the traditional knowledge of the geographical elements influencing the agricultural performance in the area. For example, the trees and shrubs forming green hedges that protected soils from drying up in the warm season and the deflation caused by occasional strong northeastern wind, especially during the cold season ("burja"), were cut off. Formation of trenches increased the occurrence of droughts, although the relative abundance of the precipitation. Social structure of agriculture was transformed from the traditional self-contained into the intensive industrialized agriculture (Črv \& Turk, 2012; Gabrijelčič et al., 1996; Kladnik \& Natek, 2001). Consequently, some morphological and structural changes were introduced (i.e., transformation of fields into meadows, attempts to re-introduce hedges, irrigation). However, the above-mentioned issues have not been properly resolved yet (Črv \& Turk, 2012).

The melioration works together with the intensive population growth and economic development caused the unsustainable development trajectory in the Vipava Valley resulting in:

- loss of fertile soil in the upper part of the Vipava Valley due to intensive wind erosion;

- intensification of drought problem that is expected to get worse due to climate changes;

- loss of biodiversity;

- intensive flooding in the lower part of the Vipava River, especially in the municipality of MirenKostanjevica, where the Vipava River has a strong curve preventing the flood water to run off; 
- pollution of the Vipava River caused by communal waste water, manufacturing and intensive agriculture.

Today, the quality of Vipava River is improving significantly. The most important investment that made it cleaner was the new wastewater treatment plant for the Nova Gorica agglomeration, but economic restructuring from industrial to service economy in the region and wastewater treatment projects in the river basin were also important. Although still seen as a threat due to the flooding especially in the lower part of the river, the identity of the Vipava River is changing. Nowadays, the locals see many possibilities for their recreation and for the development of tourism and agriculture along the Vipava River (Štangelj \& Poljšak Klaus, 2016).

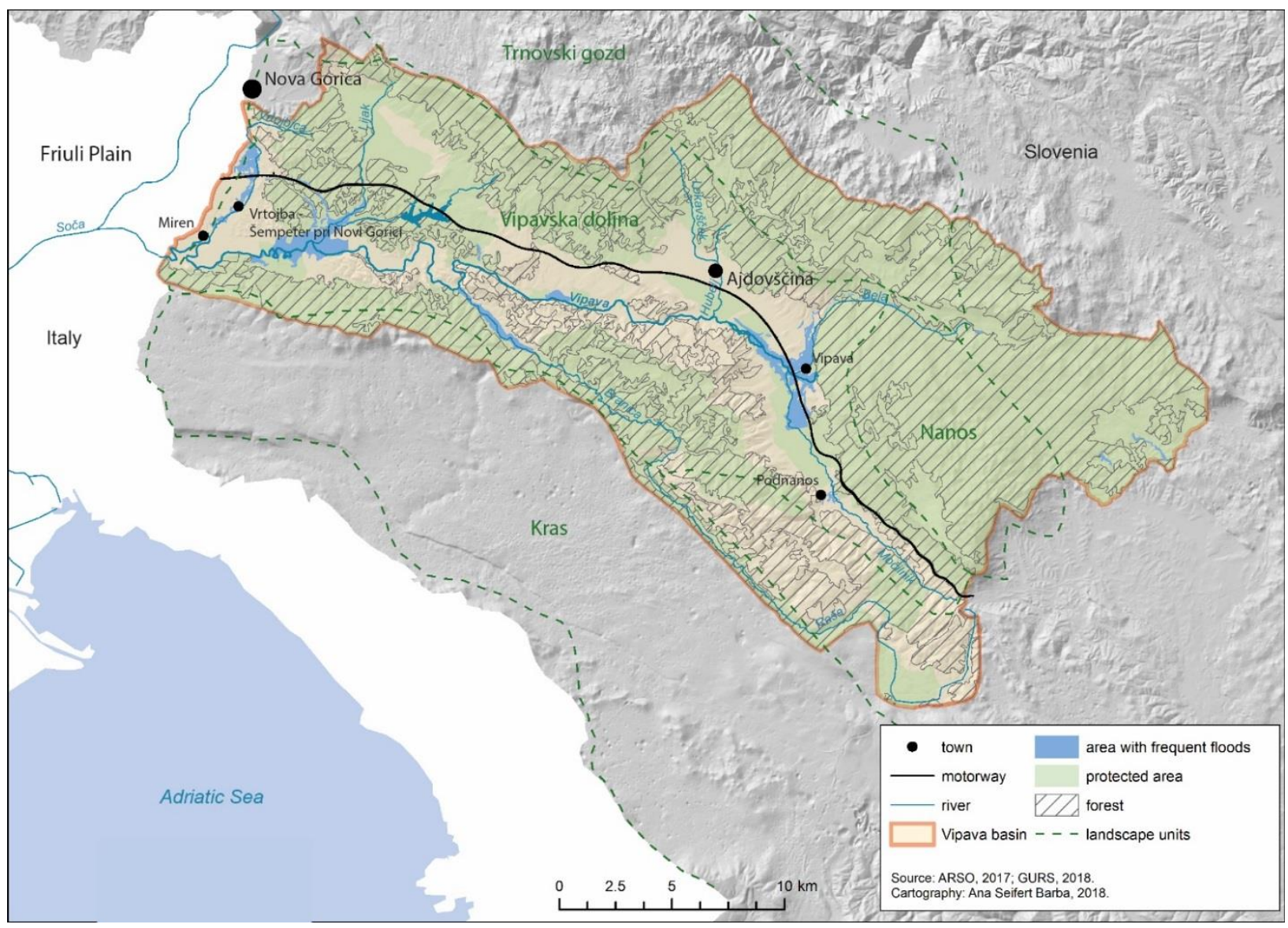

Fig 1. Location, basic geographical structure and key elements of green infrastructure in the Vipava Valley (Vipavska dolina).

The re-evaluation of the Vipava River, awareness of the development problems occurring in the Vipava Valley together with the new development possibilities, offered by the European development strategies and policies, and the enthusiasm of the empowered individuals from the region resulted in a new development initiative in 2015 named, "Vision for the Vipava River" (Vizija za Vipavo). The development initiative was started by the locals from the municipality of Miren-Kostanjevica, which is located in the lower part of the Vipava River. The development process was later guided by the geographical professional organizations (the alumni club of geographers from Ljubljana and the Association of Slovenian Geographers - Hydrogeography Commission). They used the participatory approach to involve all the relevant stakeholders at the local level. Their effort resulted in the informal document (Strokovne zasnove ureditve vodnega in obvodnega prostora ob reki Vipavi na območju občine Miren-Kostanjevica) that presented the vision, goals, principles and guidelines for the implementation of the vision on the strategic, cross-border and macro-regional level. Although the document was supposed to show new possible development directions and to serve as a professional basis for the development of the formal development vision of the territory along the Vipava River in 
the near future, it soon became the starting point for a much wider developmental process in the Vipava Valley.

The document states the new role of the Vipava River, which is a central coherent element in the Vipava Valley. It is a green infrastructure corridor that links all local communities in the area and beyond, and has the central position at recent green infrastructure planning activities in the region. The document addresses the main development issues in the region, especially the flooding and quality of water. It suggests a sustainable use of renewable resources in the region, increases the accessibility of river and ecosystem services to locals and tourists, suggests public participation in managing the territory, and puts the region and its development strategies into the wider Adriatic - Alpine - Danube macro-regional context (Bricelj et al., 2015).

Already in 2015, the document encouraged the cooperation among all municipalities in the Vipava Valley. Administratively, the Vipava Valley has six local self-governed communities (municipalities) just at the Slovenian side of the Vipava River basin, while the basin stretches also into Italy. The inter-municipal cooperation was formalized by establishing the Council for the Vipava River (Svet za Vipavo) in the same year. This council coordinates and prepares the development projects in the region, following the guidelines and propositions from the document used as a development vision for the Vipava River and development of a wider area (the region). Results of these planning efforts have not been fully seen yet, because the process is still at the planning phase. But in the middle of 2017, two cross-border development projects were prepared to apply for the tender of cross-border cooperation between Slovenia and Italy (VISFRIM addresses anti-flood protection, GREVISLIN addresses green infrastructure in the region). The first regional project regarding green infrastructure (the cycling path along the Vipava River) is ready to be implemented, some other projects are into preparation, while the first formal project focusing on green infrastructure, linking two universities from Slovenia, a local community and a company from the region that developed a model for the green infrastructure planning at the local level, has already finished.

\section{Dimensions of the Vipava Approach}

\subsection{Territorial Dimensions of the Vipava Approach}

Although the Vipava River is a relatively short stream $(49 \mathrm{~km})$, it has a central position in the Vipava Approach: the Vipava River is the most important green infrastructure element (axis) in various territorial contexts.

On the micro-regional level (the level of the the Vipava Valley), the Vipava River green axis connects smaller ecologically important sites in a more or less intensive agricultural landscape of the Vipava Valley that is surrounded by mountains and karst plateau covered by forests. The Vipava River is a central line to which other infrastructure should be directed to in order to use the ecosystem services offered by the river and the green belt around the river. The Vipava River that used to be an obstacle for the development of the region and hindered connectedness in the region is now recognized as a guiding element that enables connectivity between green infrastructure located on the periphery of the Vipava Valley and in valley's central parts longitudinally and transversally.

The mezzo-regional context has a focus on the cross-border dimension of the green infrastructure planning initiative in the region. The Vipava River green axis logically continues along the Soča River into the Northern Adriatic. Both rivers are important to connect diverse ecosystems that are present in the geographically extremely diverse landscape: the Adriatic Sea, protected area at the mouth of the Soča River, Alpine ecosystems from where the Soča River flows and the diverse landscapes of the Vipava Valley along the Vipava River with the passage to the Central Slovenia and the Danube region. 


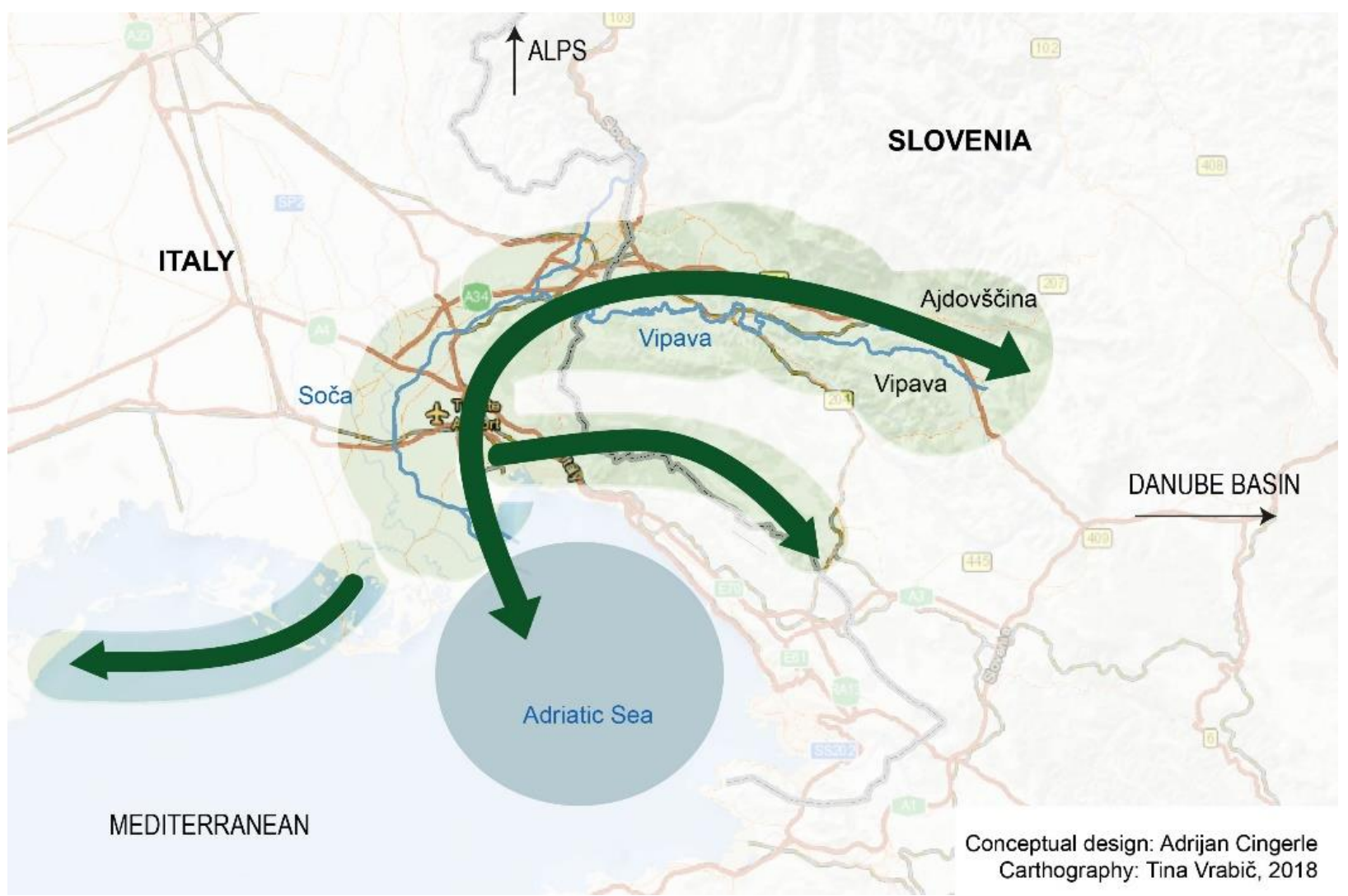

Fig 2. The mezzo-regional and the macro-regional context of the Vipava approach.

As discussed in the mezzo-regional context, the Vipava Valley is situated on the crossroad of the three European macro-regions (Alpine, Mediterranean, Danube basin); therefore, the macroregional dimension of the Vipava approach addresses overlapping these macro-regional units at the Vipava Valley.

\subsection{Institutional Dimensions of the Vipava Approach}

The Vipava Approach started as an informal initiative of locals from the municipality of MirenKostanjevica encouraged by trained geographers from national geography association and alumni of geographers form University of Ljubljana. The process was soon supported by the administration of the local community, but in the same year, it became a regional initiative as well. Although mayors in the region formalized their cooperation guided by the "vision", it needs to be pointed out, that this kind of inter-municipal cooperation is an innovative approach in Slovenia and that it developed outside the national administrative and planning management system of Slovenia. Cooperation of the municipalities in the Vipava Valley increased the role of local communities from the region in the development planning system in Slovenia, where individual municipalities are usually the weaker partner in the bargaining process compared to ministries or national planning bodies. The planning process is strongly supported also by the regional planning institutions. The informal Vision for the Vipava River offers the legitimacy of the planning process in the region and states content pillars for cooperation during the preparation phases of development projects.

New management structure in the region has led to a better coordination between various stakeholders at preparing development projects, better inclusion of local needs into development projects, better supervision on the planning process and the number of relevant stakeholders has expanded (locals, universities, development agencies). By preparing cross-border development projects VISFRIM and GREVISLIN, partners from the Italian side of the programming region will also be introduced into the Vipava Approach. Macro-regional dimension brings new development potentials and opportunities for green infrastructure development in the region and can serve as 
a study case on how to implement European strategy of the green infrastructure with implications on various European territorial scales by using mechanisms offered by the European macroregional strategies and European Union cohesion policy financial instruments.

\subsection{Green infrastructure in the Context of Sustainable Spatial Development at the Vipava Approach}

Vision for the Vipava River puts green infrastructure in a developmental context, where green infrastructure is not just larger green areas and corridors between them to enable migration of animals but also infrastructure that enables sustainable use of ecosystem services offered by the green infrastructure.

Elements of green infrastructure are also soft regulations of the river and along the river (paths to access the river, anchorages for boats, swimming and sunbathing areas, areas for fishing, birdwatching areas) together with walking and cycling paths that connect river to already existent walking and cycling infrastructure. The river is used also as a longitudinal corridor enabling intraregional and inter-regional communication (Bricelj et al., 2015). Sustainable use of ecosystem services offered by green infrastructure is a starting point for the multifunctional use of the Vipava River for the anti-flood protection, strengthening the ecosystem services (spatial and environmental dimension), returning river to the inhabitants (social dimension) and the development of green economy (economic dimension of sustainable development).

Tab 1. Dimensions of the the Vipava Approach. Source: Elaborated by the author

\begin{tabular}{|l|l|}
\hline $\begin{array}{l}\text { Territorial } \\
\text { dimension }\end{array}$ & Content - keywords \\
\hline Local & $\begin{array}{l}\text { Returning rivers to inhabitants: embankments cleaning, access to river, } \\
\text { recreation on/along the river, multifunctional use of water }\end{array}$ \\
\hline Regional & $\begin{array}{l}\text { Inter-municipal cooperation: common vision, cycling paths, anti-flood } \\
\text { protection, resilience to climate change }\end{array}$ \\
\hline National & Pilot approach: implementation of EU cohesion and national regional policy \\
\hline $\begin{array}{l}\text { Macro- } \\
\text { regional }\end{array}$ & $\begin{array}{l}\text { Cross-border cooperation, implementation of macro-regional strategies: anti- } \\
\text { flood protection, ecosystem services, river basin management plans }\end{array}$ \\
\hline
\end{tabular}

Even more, green infrastructure is also a starting point and a guidance for addressing other spatial problems in the region: formation of a common development vision, sustainable mobility, antiflood protection, strengthening ecosystem services, protection of the environment and resilience to climate changes. To achieve goals of the sustainable spatial development in the region and to strengthen the ecosystem services of green infrastructure, different instruments can be used like eco-remediation, linking isolated green infrastructure areas into the coherent system, multifunctional use of water in the river and in multipurpose restraints, changes in crops and similar (instruments will be developed in the GREVISLIN project). Spatial issues that have the cross-border and the macro-regional relevance can be addressed the same way.

\section{Discussion and Conclusions}

The Vipava Approach is a novel approach in addressing the green infrastructure planning in Slovenia with four main characteristics that needs to be pointed out: (1) it is a bottom-up approach that is not centrally planned (i.e., by responsible ministries or national planning agencies); (2) it is still in progress, making it difficult to analyse and evaluate all of its relevant aspects; (3) green infrastructure is seen in the broader developmental context and not only as a protection or conservation; (4) it is an application of the green infrastructure concept in a rural setting, on both, local and regional levels.

Territorial scale of the Vipava Approach is not an administrative or political unit as it is the case in the traditional top-down planning approaches, but a new planning region formed because of 
needs and interests of locals. Municipalites from the Vipava Valley decided to cooperate voluntarily to make development in the Vipava Valley more sustainable. They formalized their decision by establishing the Vipava Council that will be responsible for the implementation of the principles of the green infrastructure approach to address main spatial problems in Vipava Valley: degradation of soils, floods and water pollution. Since the Vipava Approach is put into a wider territorial scale of the cross-border, mezzo-regional and macro-regional scale, the Lafforteza et al.'s (2013) notion about differences in planning approach between the macroterritorial levels and the local-regional scale is just partly relevant in the studied case. The planning approach used in the Vipava Valley has been adopted also on upper territorial levels, but it had to adapt to formal planning tools and approaches used at the upper territorial levels. Nevertheless, the Vipava Approach highlights the importance of the local level and the bottom-up approach as a basis for the participatory planning of green infrastructure in rural areas. Our findings correspond to Mell (2015) that green infrastructure approaches become increasingly focused towards the local. Their application are viewed as being more suitable to local needs compared to discussion within regional, national or international policy. Flexibility of forming green infrastructure policy (Wright, 2011) provides scope for policy-makers and practitioners to apply the concept in most locally appropriate manner.

The Vipava Approach highlights not only land-use and protection issues as suggested by Allen III (2012) and Amundsen et al. (2009), but also the ecosystem values and functions that provide diverse recreational, social and economic benefits to human population by giving equal importance to cultural and amenity functions and not just traditionally more important regulating and provisioning ecosystem services. Therefore, the Vipava Approach is not just about conservation and protection but it is more holistic (Kambites \& Owen, 206; Aherm, 2013); it is about development that follows the principles of sustainable development, trying to make better connections between land use planning and socio-economic and ecological outcome targeting the sustainable spatial development issues of a rural area.

Since the Vipava Approach is still in planning phase, we cannot predict all possible dimensions and outcomes. One of the most important questions is the relatively fast spatial re-focus from the local to the regional level without time to fully develop and implement the new approach on the local level. There is an open dilemma if organic development of the approach was not overcome by money chasing from the European Union and national funds and implementing interests of individual project partners, thinking mainly through the eyes of the grey infrastructure development approach. Therefore, a renovated development document "Vision for Vipava" that would upgrade local initiative to new circumstances is needed and, of equal importance, a regional green infrastructure strategic (spatial) plan as an implementation of the vision is required. In other words, we see a strategic plan on the regional level as the most important instrument for the development of green infrastructure in a way that would help stakeholders to follow the Vipava Approach agenda fully without narrowing the Vipava Approach only on the landuse dimension.

In summary, it is clear, that the Vipava Approach have already become an innovative platform enabling the cooperation between various stakeholders from different territorial levels and sectors, residents and professional planners, practitioners and academics. This new arena enables the formation of a common vision of the sustainable development of the Vipava Valley. The main instrument for implementation of the vision will be the green infrastructure strategic development plan that will define not just sustainable multifunctional use of the Vipava River but also encourage development of innovative tools for coping unsustainable development trajectory in the region and future global development challenges of the studied rural area.

\section{Acknowledgements}

The author of the article is very grateful to Branko Pavlin, $\mathrm{PhD}$, geographer and the empowered local, who invited him to participate in the fascinating green infrastructure planning process in the Miren-Kostanjevica municipality and the Vipava Valley. 
[1] Ahern, J. (2013). Urban landscape sustainability and resilience: the promise and challenges of integrating ecology with urban planning and design. Landscape Ecology 28 (6), 12031212. DOI: $10.1007 / \mathrm{s} 10980-012-9799-\mathrm{z}$.

[2] Allen III, W. L. (2012). Advancing Green Infrastructure at All Scales: From Landscape to Site. Environmental Practice 14, 17-25. DOI: 10.1017/S1466046611000469.

[3] Amundsen, O. M., Allen, W. \& Hoellen, K. (2009). Green Infrastructure Planning: Recent Advances and Applications. Washington: American Planning Association.

[4] Andersson, K., Angelstam, P., Elbakidze, M., Axelsson, R. \& Degerman, E. (2013). Green infrastructures and intensive forestry: Need and opportunity for spatial planning in a Swedish rural-urban gradient. Scandinavian Journal of Forest Research 28(2), 143-165. DOI: 10.1080/02827581.2012.723740.

[5] Benedict, M. A. \& McMahon, E. T. (2002). Green infrastructure smart conservation for the $21^{\text {st }}$ century. Renewable Resources Journal 20(3), 12-17.

[6] Bokal, G., Goljevšček, A., Halilović, N., Kožar, T., Kresnik, K., Pečan, P., Sekereš, S. \& Vehovec, M. (2017a). Pristop k načrtovanju zelene infrastructure na lokalni ravni: primer občine Miren-Kostanjevica. Urbani izziv, 28(1), 123-131.

[7] Bokal, G., Goljevšček, A., Halilović, N., Kožar T., Kresnik, K., Pečan, P., Sekereš, S. \& Vehovec, M. (2017b). Nazaj k naravi, naprej k Vipavi: Načrtovanje in pilotni ukrepi zelene infrastrukture ob reki Vipavi $v$ občini Miren-Kostanjevica (ZelnViM) [Research report]. Ljubljana: Univerza v Ljubljani.

[8] Bricelj, M., Pavlin, B., Pečar, J., Kušar, S. \& Draksler, A. (2015). Strokovne zasnove ureditve vodnega in obvodnega prostora ob reki Vipavi na območju občine Miren-Kostanjevica. Miren: Alumni klub geografov Univerze v Ljubljani, Občina Miren-Kostanjevica, Komisija za hidrogeografijo Zveze geografov Slovenije.

[9] Bulc, G., Ameršek, I. \& Dovjak, M. (2014). Green infrastructure in settlements and cities of the future - two cases studies: green roof and treatment wetland. International Journal of Sanitary Engineering Research, Special edition, 67-80.

[10] Črv, R. \& Turk, M. (2012). Melioracije in pomen vetrozaščitnih pasov v Vipavski dolini. URL: http://giam2.zrc-sazu.si/sites/default/files/crv_turk_melioracije_vipavska_dolina.pdf.

[11] Elbakidze, M., Angelstam, P., Yamelynets, T., Dawson, L., Gebrehiwot, M., Stryamets, N., Johansson, K-E., Garrido, P., Naumov, V. \& Manton, M. (2017). A bottom-up approach to map land covers as potential green infrastructure hubs for human well-being in rural settings: A case study from Sweden. Landscape and Urban Planning, 168, 72-83. DOI: 10.1016/j.landurbplan.2017.09.031.

[12] Gabrijelčič, Z., Ušaj, H., Kodrič, I., Poženel, A., Gorkič, M. \& Osmuk, N. (1996). Vipavska dolina včeraj, danes, jutri. In Urejenost voda - osnova ali omejitev (pp. 85-98). Maribor: Vodnogospodarski biro Maribor.

[13] De Groot, R. S., Alkmende, R., Braat, L., Hein, L. \& Willemen, L. (2010). Challenges in integrating the concept of ecosystem services and values in landscape planning, management and decision making. Ecological Complexity 7, 260-272. DOI: 10.1016/j.ecocom.2009.10-0006.

[14] Kambites, C. \& Owen, S. (2006). Renewed prospects for green infrastructure planning in the UK. Planning Practice and Research 21(4), 483-496. DOI: 10.1080/02697450601173413.

[15] Kladnik, D. \& Natek, M. (2001). Vipavska dolina. In Perko, D. \& Orožen Adamič, M., eds., Slovenija: pokrajine in ljudje (pp. 222-233). Ljubljana: Založba Mladinska knjiga. 
[16] Kolcsár, R. A. \& Szilassi, P. (2018). Assessing accessibility of urban green spaces based on isochrone maps and street resolution population data through the example of Zalaegerszeg, Hungary. Carpathian Journal of Earth and Environmental Sciences 13(1), 31-36. DOI:10.26471/cjees/2018/013/003.

[17] Lafortezza, R., Davies, C., Sanesi, G. \& Konijnendijk, C. C. (2013). Green Infrastructure as a tool to support spatial planning in European urban regions. iForest 6, 102-108. DOI: 10.3832/ifor0723-006.

[18] Lerner, J. \& Allen, W, L. (2012). Landscape-scale green infrastructure investments as a climate adaptation strategy: a case example for the Midwest United States. Environmental Practice 14(1), 45-56. DOI: 10.1017/S146604661100055X.

[19] Mell, I. C. (2010). Green Infrastructure: concepts, perceptions and its use in spatial planning. Newcastle upon Tyne: Newcastle University.

[20] Mell, I. C. (2013). Can you tell a green field from a cold steel rail? Examining the "green" of green infrastructure development. Local environment: The International Journal of Justice and Sustainability 18(2), 37-41. DOI: 10.1080/13549839.2012.719019.

[21] Mell, I. (2015). Green infrastructure planning: policy and objectives. In Sinnett, D., Smith, N. \& Burgess, S., eds., Handbook of Green Infrastructure: Planning, Design and Implementation (pp. 105-123). Cheltenham: Edward Elgar Publishing.

[22] Nastran, M. \& Železnikar, Š. (2016). Invasive alien plant species on urban green areas. In Jurc, M. \& Borkovič, D., eds., Invasive alien species in forests and their impact on the sustainable use of forest resources (pp. 243-251). Ljubljana: University of Ljubljana.

[23] Naumann, S., Davis, McK., Kaphengest, T., Pieterse, M. \& Rayment, M. (2011). Design, implementation and cost elements of Green Infrastructure projects [Final report to European Commission]. Brussels: DG.

[24] Oteros-Rozas, E., Martín-López, B., González, J., Plieninger, T., López, C. \& Montes, C. (2014). Socio-cultural valuation of ecosystem services in a transhumance socialecological network. Regional Environmental Change 14, 1269-1289. DOI: 10.1007/s10113-013-0571y.

[25] Penko Seidl., N., Bončina, A. \& Pintar, M. (2017). Strokovna podpora fokusnim skupinam v sklopu priprave Strategije prostorskega razvoja Slovenije 2030: Podeželje in Zelena infrastruktura. Ljubljana: Univerza v Ljubljani.

[26] Scholte, S., Teeffelen, A. \& Verburg, P. (2015). Integrating socio-cultural perspectives into ecosystem service valuation: A review of concepts and methods. Ecological Economics 114, 67-78. DOI: 10.1016/j.ecolecon.2015.03.007.

[27] Štangelj, T. \& Poljšak Klaus, P. (2016). Pogledi domačinov na prihodnji razvoj ob reki Vipavi. In Kušar, S., ed., Pogledi na trajnostni razvoj or reki Vipavi v občini Miren-Kostanjevica (pp. 2-5). Ljubljana: Univerza v Ljubljani.

[28] Villamor, G., Palomo, I., Santiago, C., Oteros-Rozas, E. \& Hill, J. (2014). Assessing stakeholders' perceptions and values towards social-ecological systems using participatory methods. Ecological Processes 3, 1-12. DOI: 10.1186/s13717-014-0022-9.

[29] Železnikar, Š., Eler, K. \& Pintar, M. (2017). City hotspot: linkages between ecosystem services and biodiversity of urban green areas. Acta Agriculturae Slovenica 109(1), 111123. DOI: 10. 14720/aas.2017.109.1.11.

[30] Wright, H. (2011). Understanding green infrastructure: the development of a contested concept in England. Local environment: The International Journal of Justice and Sustainability 16(10), 37-41. DOI: 10.1080/13549839.2011.631993. 
[31] European Commission (2013). Communication from the Commission to the European Parliament, the Council, the European Economic and Social Committee and the Committee of the Regions: Green infrastructure (Gl): Enhancing Europe's Natural Capital. Brussels: European Commission.

[32] European Environment Agency (2011). Green Infrastructure and Territorial Cohesion: The concept of Green Infrastructure and Its Integration into Policies Using Monitoring Systems. Brussels: European Environment agency. 